\title{
Cerebellar tDCS: How to Do It
}

\author{
Roberta Ferrucci • Francesca Cortese • Alberto Priori
}

Published online: 18 September 2014

(C) The Author(s) 2014. This article is published with open access at Springerlink.com

\begin{abstract}
Cerebellar transcranial direct current stimulation (cerebellar tDCS) is a non-invasive technique for inducing prolonged functional changes in the human cerebellum. Available data show that this simple and safe technique can modulate several motor and non-motor cerebellar functions in healthy humans. Also, preliminary data suggest that cerebellar tDCS is a possible therapeutic option in patients with cerebellar disorders. To provide a reference for those approaching this technique for the first time in healthy humans and patients, we here briefly and practically review the methodology for cerebellar tDCS, discussing electrode types, positions, DC duration and intensity. Recent modelling studies confirm that the electric field generated with the methodology reviewed here reaches the cerebellum at a strength within the range of values for modulating activity in the cerebellar neurons experimentally assessed.
\end{abstract}

Keywords Cerebellar tDCS · Electrode position - Polarity . Intensity $\cdot$ Cerebellar stimulation $\cdot$ Ataxia

\section{Introduction}

Cerebellar transcranial direct current stimulation (cerebellar tDCS) is increasingly used in neurophysiology laboratories, and its use begins in clinical research [1,2]. The technique

R. Ferrucci $\cdot$ F. Cortese $\cdot$ A. Priori $(\bowtie)$

Centro Clinico per la Neurostimolazione, le Neurotecnologie e i Disordini del Movimento, Fondazione IRCCS Ca' Granda Ospedale Maggiore Policlinico, Milan, Italy

e-mail: alberto.priori@unimi.it

R. Ferrucci · A. Priori

Dipartimento di Fisiopatologia Medico Chirurgica e dei Trapianti, Università degli Studi di Milano, Milan, Italy consists in delivering for minutes through a surface scalp electrode a weak (1-2 mA) direct current over the cerebellum. The technique is painless, and stimulation can be delivered during any motor or cognitive activity. Research findings (for a review, see [2]) already provide evidence that cerebellar tDCS can induce neurophysiological changes in the cerebello-brain interaction [3-6] and can influence gait adaptation [7], motor learning [8-12] and cognition [13-18] in healthy humans. Preliminary clinical observations suggest that the changes induced by cerebellar tDCS could be clinically useful in patients with various disorders involving cerebellar dysfunction [19, 20].

Though current evidence leaves open possible (transynaptic or antidromic) changes in other brain or brainstem structures, the physiological effects elicited by cerebellar tDCS arise mainly from functional changes in the cerebellum itself. Cerebellar tDCS could interfere with membrane polarisation in Purkinje cells and in other neurons, fibres (mossy fibres and climbing fibres) and glial cells. DC stimulation applied to the cerebellar cortex in the decerebrated cat influences Purkinje and granular cell activity in a polarity-specific manner; while anodal DC (0.1-1 mA) flowing in the dendrite-axonal direction increases tonic neuronal activity, cathodal DC decreases it [21].

Given the technique's growing popularity among neuroscientists, for the reader approaching cerebellar tDCS for the first time, we believe it to be useful to describe its methodology. This description has a preliminary limitation; however, insofar, most of the critical methodological variables (for instance, stimulation duration and intensity, number of sessions) have been so far empirically set and no systematic studies have yet assessed how they influence the effects elicited by cerebellar tDCS. Throughout the text, we refer to data available in the literature summarized in Table 1. 
Table 1 Cerebellar tDCS protocols. Studies with (A) two electrodes over the two cerebellar hemispheres (top) or one electrode over the whole cerebellum (bottom), and (B) electrodes over one cerebellar hemisphere.
Note that the position of the reference electrode and stimulation parameters (intensity, duration, electrode size) differed across the various studies

\begin{tabular}{|c|c|c|c|c|c|}
\hline & Authors & Year & Polarity & Montage & Parameters \\
\hline \multicolumn{6}{|c|}{ A: THE WHOLE CEREBELLUM: $1-2 \mathrm{~cm}$ below the inion with its lateral borders about $1 \mathrm{~cm}$ medially to the mastoid apophysis } \\
\hline & Ferrucci et al. & 2008 & AnodallCathodallSham & $\begin{array}{l}\text { Active electrodes (elliptical) over the cerebellum } \\
\text { (bilaterally) } \\
\text { Reference on the right shoulder }\end{array}$ & $\begin{array}{l}2 \mathrm{~mA} ; 15 \mathrm{~min} ; \\
\mathrm{ES}=21 \mathrm{~cm}\end{array}$ \\
\hline & Ferrucci et al. & 2013 & AnodallSham & $\begin{array}{l}\text { Active electrode over the cerebellum } \\
\text { Reference on the right shoulder }\end{array}$ & $\begin{array}{l}2 \mathrm{~mA} ; 20 \mathrm{~min} \\
\mathrm{ES}=35 \mathrm{~cm}\end{array}$ \\
\hline & Ferrucci et al. & 2013 & AnodallCathodallSham & $\begin{array}{l}\text { Active electrode over the cerebellum } \\
\text { Reference on the right shoulder }\end{array}$ & $\begin{array}{l}2 \mathrm{~mA} ; 20 \mathrm{~min} \\
\mathrm{ES}=35 \mathrm{~cm}^{2}\end{array}$ \\
\hline \multicolumn{6}{|c|}{ B: ONE CEREBELLAR HEMISPHERE: $1-2 \mathrm{~cm}$ below and $3-4 \mathrm{~cm}$ lateral to the inion } \\
\hline & Galea et al. & 2009 & AnodallCathodallSham & $\begin{array}{l}\text { Active electrode over the right cerebellum } \\
\text { Reference on the ipsilateral buccinator muscle }\end{array}$ & $\begin{array}{l}2 \mathrm{~mA} ; 25 \mathrm{~min} \\
\mathrm{ES}=25 \mathrm{~cm}^{2}\end{array}$ \\
\hline & Jayaram et al. & 2012 & AnodallCathodallSham & $\begin{array}{l}\text { Active electrode over the right/left cerebellum } \\
\text { Reference on the ipsilateral buccinator muscle }\end{array}$ & $\begin{array}{l}2 \mathrm{~mA} ; 15 \mathrm{~min} \\
\mathrm{ES}=25 \mathrm{~cm}^{2}\end{array}$ \\
\hline & Galea et al. & 2012 & AnodallSham & $\begin{array}{l}\text { Active electrode over the right cerebellum } \\
\text { Reference on the ipsilateral buccinator muscle }\end{array}$ & $\begin{array}{l}2 \mathrm{~mA} ; 15 \mathrm{~min} \\
\mathrm{ES}=25 \mathrm{~cm}^{2}\end{array}$ \\
\hline & Hamada et al. & 2012 & AnodallCathodallSham & $\begin{array}{l}\text { Active electrode over the right cerebellum } \\
\text { Reference on the ipsilateral buccinator muscle }\end{array}$ & $\begin{array}{l}2 \mathrm{~mA} ; 15 \mathrm{~min} \\
\mathrm{ES}=25 \mathrm{~cm}^{2}\end{array}$ \\
\hline & Boehringer et al. & 2012 & CathodallSham & $\begin{array}{l}\text { Active electrode over the right cerebellum } \\
\text { Reference on the buccinator muscle }\end{array}$ & $\begin{array}{l}2 \mathrm{~mA} ; 25 \mathrm{~min} \\
\mathrm{ES}=25 \mathrm{~cm}^{2}\end{array}$ \\
\hline & Pope and Miall & 2012 & AnodallCathodallSham & $\begin{array}{l}\text { Active electrode over the right cerebellum } \\
\text { Reference on the right shoulder }\end{array}$ & $\begin{array}{l}2 \mathrm{~mA} ; 20 \mathrm{~min} \\
\mathrm{ES}=25 \mathrm{~cm}^{2}\end{array}$ \\
\hline & Sadnika et al. & 2013 & AnodallCathodallSham & $\begin{array}{l}\text { Active electrode over the right cerebellum } \\
\text { Reference on the ipsilateral buccinator muscle }\end{array}$ & $\begin{array}{l}2 \mathrm{~mA} ; 20 \mathrm{~min} \\
\mathrm{ES}=25 \mathrm{~cm}^{2}\end{array}$ \\
\hline & Shah et al. & 2013 & AnodallCathodallSham & $\begin{array}{l}\text { Active electrode over the non dominant cerebellum } \\
\text { Reference over the ipsilateral buccinator muscle }\end{array}$ & $\begin{array}{l}1 \mathrm{~mA} ; 15 \mathrm{~min} \\
\mathrm{ES}=8 \mathrm{~cm}^{2}\end{array}$ \\
\hline & $\begin{array}{l}\text { Grimaldi \& } \\
\text { Manto }\end{array}$ & 2013 & AnodallCathodallSham & $\begin{array}{l}\text { Active electrode over the right cerebellum } \\
\text { Reference on the contralateral supra-orbital area }\end{array}$ & $\begin{array}{l}1 \mathrm{~mA} ; 20 \mathrm{~min} \\
\mathrm{ES}=20 \mathrm{~cm}^{2}\end{array}$ \\
\hline & Chen et al. & 2014 & AnodallCathodallSham & $\begin{array}{l}\text { Active electrode over the right cerebellum } \\
\text { Reference on the right buccinator muscle }\end{array}$ & $\begin{array}{l}2 \mathrm{~mA} ; 25 \mathrm{~min} ; \\
\mathrm{ES}=25 \mathrm{~cm}^{2}\end{array}$ \\
\hline & Dutta et al. & 2014 & AnodallSham & $\begin{array}{l}\text { Active electrode over the left cerebellum } \\
\text { Reference on the forehead above the right } \\
\text { supraorbital ridge }\end{array}$ & $\begin{array}{l}1 \mathrm{~mA} ; 15 \mathrm{~min} \\
\mathrm{ES}=35 \mathrm{~cm}^{2}\end{array}$ \\
\hline & Grimaldi et al. & 2014 & AnodallSham & $\begin{array}{l}\text { Active electrode over the right cerebellum followed by } \\
\text { contralateral motor cortex } \\
\text { Reference on the contralateral supra-orbital area }\end{array}$ & $\begin{array}{l}1 \mathrm{~mA} ; 20 \mathrm{~min} \\
\mathrm{ES}=20 \mathrm{~cm}^{2}\end{array}$ \\
\hline & $\begin{array}{l}\text { Hardwick \& } \\
\text { Celnik }\end{array}$ & 2014 & AnodallSham & $\begin{array}{l}\text { Active electrode over the lateral cerebellum } \\
\text { (dominant hand) } \\
\text { Reference on the Ipsilateral buccinators muscle }\end{array}$ & $\begin{array}{l}2 \mathrm{~mA} ; 15 \mathrm{~min} \\
\mathrm{ES}=25 \mathrm{~cm}^{2}\end{array}$ \\
\hline & Macher et al. & 2014 & AnodallCathodallSham & $\begin{array}{l}\text { Active electrode over the right cerebellum } \\
\text { Reference on the right buccinator muscle }\end{array}$ & $\begin{array}{l}2 \mathrm{~mA} ; 25 \mathrm{~min} \\
\mathrm{ES}=25 \mathrm{~cm}^{2}\end{array}$ \\
\hline & Zuchowski et al. & 2014 & AnodallShamlCathodal & $\begin{array}{l}\text { Active electrode over the right cerebellum } \\
\text { Reference on the right buccinator muscle }\end{array}$ & $\begin{array}{l}2 \mathrm{~mA} \text {; during the } \\
\text { acquisition phase } \\
\mathrm{ES}=35 \mathrm{~cm}^{2}\end{array}$ \\
\hline & Herzfeld et al. & 2014 & AnodallShamlCathodal & $\begin{array}{l}\text { Active electrode over the right cerebellum } \\
\text { Reference on the right buccinator muscle }\end{array}$ & $\begin{array}{l}2 \mathrm{~mA} ; 25 \mathrm{~min} ; \\
\mathrm{ES}=25 \mathrm{~cm}^{2}\end{array}$ \\
\hline
\end{tabular}

$m A$ milliampere, min minutes, ES electrode size

\section{Electrodes}

Cerebellar tDCS is usually delivered through two rectangular sponge electrodes embedded in a saline-soaked solution ( $\mathrm{NaCl}$ concentration between 15 to $140 \mathrm{mM}$ ) [22]. Electrode size varies; to stimulate half of the cerebellum, most researchers use a single electrode measuring $5 \mathrm{~cm} \times 5 \mathrm{~cm}$ (area $\left.25 \mathrm{~cm}^{2}\right)[3-5,7,9-11,13,17,18]$ while stimulating the whole cerebellum requires a larger electrode measuring about $7 \times$ $5 \mathrm{~cm}\left(\right.$ area $\left.35 \mathrm{~cm}^{2}\right)[14,15]$.

\section{Electrode Position}

The stimulating electrode is placed over the cerebellum and the other (return electrode) over the buccinator muscle $[3-13,18,23]$ or the right shoulders [14-17]. The return electrode can also be placed over the scalp $[8,19,20]$. The stimulating electrode can be placed over one or two cerebellar hemisphere $(1-2 \mathrm{~cm}$ below and $3-4 \mathrm{~cm}$ lateral to the inion) $[3-13,16-20,23]$ or on the median line over the whole cerebellum $(1-2 \mathrm{~cm}$ below the inion with its lateral 
borders about $1 \mathrm{~cm}$ medially to the mastoid apophysis) [14, 15] (Table 1).

A key technical point is that because the effects induced by cerebellar tDCS probably depend to a certain extent on the current flow direction and electrical field orientation, the elicited changes depend on the position chosen for the return electrode. For instance, moving the return electrode from the forehead to the ipsilateral cheek over the buccinator muscle changes cerebellar tDCS effects on visuomotor integration $[8$, 12]. Modelling studies show that with the return electrode over the right shoulder, cerebellar tDCS targets the posterior cerebellum in the adult, with a slight spread to the brainstem in children [24].

After careful skin cleaning, electrodes can be secured in position with an elastic tubular netting or an ergonomic cap. A conductive electrolyte gel can be used between the electrode and the skin (see preceding section). To reduce the risk of burns below the electrodes, electrodes should not be placed over scars, nevi or any other skin abnormalities that could change skin resistance, nor should they be positioned over skull holes or fractures.

\section{Intensity and Duration}

Both electrodes are connected to a standard tDCS stimulator, delivering DC for 15-25 min, at an intensity ranging from 1 to $2 \mathrm{~mA}$. Experimental studies so far reported that the cerebellum has been stimulated with a charge ranging from 0.9 to $2.4 \mathrm{C}$. This stimulation intensity induces an electric field of the same order of magnitude as that influencing the cerebellar neuron activity in animal experiments [2].

\section{Polarity of Stimulation}

Because cerebellar tDCS has been assessed using different variables (neurophysiological, cognitive, affective, behavioural) with heterogeneous methodologies, interpreting the effects induced by anodal or cathodal stimulation is a far more complex task for cerebellar tDCS than for cerebral tDCS. In essence, when the anodal electrode is placed over the cerebellum, non-motor functions (implicit learning, mismatch negativity) and motor functions in healthy subjects (walking task, visuomotor learning, motor adaptation, eye-blink conditioning, force field learning) and in ataxic patients (tremor and dysmetria) improve. Conversely, when the stimulating electrode is the cathode, memory, split belt walk, paired associative stimulation (PAS), eye-blink conditioning and force field learning worsen in healthy subjects. In some experiments, both polarities induced the same effects. The same polarity with the return electrode placed in a different position could induce different effects [2].

\section{Adverse Effects}

During stimulation in our experience, subjects can perceive a metallic taste and sometimes an itching and tingling sensation below the reference electrode (right shoulders). When cerebellar tDCS ends, subjects often report feeling more motivated and active.

After cerebellar tDCS given within the intensity and duration described here, no subjects have reported adverse effects, nor have patients reported symptoms or signs of cerebellar dysfunction. In most subjects, cerebellar tDCS evokes no sensation probably because cutaneous nerves in the occipital region have a higher threshold than those in the frontal trigeminal dermatomes [25]. If the subject complains of persistent pain or a burning sensation below the tDCS electrodes, the stimulation should be stopped and the skin below the electrodes should be carefully inspected. If there is no redness or lesion, more conductive gel or saline can be added below the electrodes and stimulation can be resumed. If pain or discomfort or both complaints persist, stimulation should be stopped. Because tDCS can spread to the brainstem in children, the technique should be avoided in the paediatric population until systematic and specific safety data are available for children. Other precautions and contraindications are the same as those for cerebral tDCS [26].

\section{Future Directions}

Several methodological variables for cerebellar tDCS remain to be systematically assessed. For example, we need to investigate changes induced by repeated stimulation sessions, compare stimulating electrode montages, examine how body size and age could influence results and study interactions with ongoing drug treatments, the possible effects of random noise or alternating current stimulation and the combined effects of multiple stimulation targets. Multi-target DC stimulation is a fascinating new direction: DC could be used to stimulate the cerebellum, spinal cord and cerebral cortex simultaneously, thus possibly enhancing the induced effects or eliciting still unexplored neuromodulatory responses.

Conflict of Interest Alberto Priori and Roberta Ferrucci are stakeholders in Newronika s.r.l., a spin-off company formed by the Fondazione IRCCS Ca' Granda Ospedale Maggiore Policlinico and Università degli Studi di Milano.

Open Access This article is distributed under the terms of the Creative Commons Attribution License which permits any use, distribution, and reproduction in any medium, provided the original author(s) and the source are credited. 


\section{References}

1. Ferrucci R, Priori A. Transcranial cerebellar direct current stimulation (tcDCS): motor control, cognition, learning and emotions. NeuroImage. 2013;85(Pt 3):918-23.

2. Priori A, Ciocca M, Parazzini M, Vergari M, Ferrucci R. Transcranial cerebellar direct current stimulation and transcutaneous spinal cord direct current stimulation as innovative tools for neuroscientists. J Physiol. 2014;592(Pt 16):3345-69.

3. Chen JC, Hammerer D, D’Ostilio K, Casula EP, Marshall L, Tsai CH, et al. Bi-directional modulation of somatosensory mismatch negativity with transcranial direct current stimulation: an event related potential study. J Physiol. 2014;592(Pt 4):745-57.

4. Galea JM, Jayaram G, Ajagbe L, Celnik P. Modulation of cerebellar excitability by polarity-specific noninvasive direct current stimulation. J Neurosci. 2009;29(28):9115-22.

5. Hamada M, Strigaro G, Murase N, Sadnicka A, Galea JM, Edwards MJ, et al. Cerebellar modulation of human associative plasticity. J Physiol. 2012;590(Pt 10):2365-74.

6. Zuchowski ML, Timmann D, Gerwig M. Acquisition of conditioned eyeblink responses is modulated by cerebellar tDCS. Brain Stimul. 2014;7:525-31. doi: 10.1016/j.brs.2014.03.010 .

7. Jayaram G, Tang B, Pallegadda R, Vasudevan EV, Celnik P, Bastian A. Modulating locomotor adaptation with cerebellar stimulation. J Neurophysiol. 2012;107(11):2950-7.

8. Dutta A, Paulus W, Nitsche MA. Facilitating myoelectric-control with transcranial direct current stimulation: a preliminary study in healthy humans. JNER. 2014;11:13.

9. Galea JM, Vazquez A, Pasricha N, de Xivry JJ, Celnik P. Dissociating the roles of the cerebellum and motor cortex during adaptive learning: the motor cortex retains what the cerebellum learns. Cereb Cortex. 2012;21(8):1761-70.

10. Hardwick RM, Celnik PA. Cerebellar direct current stimulation enhances motor learning in older adults. Neurobiol Aging. 2014;35(10): 2217-21. doi: 10.1016/j.neurobiolaging.2014.03.030 .

11. Herzfeld DJ, Pastor D, Haith AM, Rossetti Y, Shadmehr R, O'Shea J. Contributions of the cerebellum and the motor cortex to acquisition and retention of motor memories. NeuroImage. 2014;98:147-58. doi: 10.1016/j.neuroimage.2014.04.076 .

12. Shah B, Nguyen TT, Madhavan S. Polarity independent effects of cerebellar tDCS on short term ankle visuomotor learning. Brain Stim. 2013;6(6):966-8.

13. Boehringer A, Macher K, Dukart J, Villringer A, Pleger B. Cerebellar transcranial direct current stimulation modulates verbal working memory. Brain Stim. 2012;6(4):649-53.
14. Ferrucci R, Brunoni AR, Parazzini M, Vergari M, Rossi E, Fumagalli $\mathrm{M}$, et al. Modulating human procedural learning by cerebellar transcranial direct current stimulation. Cerebellum. 2013;12(4):485-92.

15. Ferrucci R, Giannicola G, Rosa M, Fumagalli M, Boggio PS, Hallett $\mathrm{M}$, et al. Cerebellum and processing of negative facial emotions: cerebellar transcranial DC stimulation specifically enhances the emotional recognition of facial anger and sadness. Cogn Emot. 2012;26(5):786-99.

16. Ferrucci R, Marceglia S, Vergari M, Cogiamanian F, Mrakic-Sposta $\mathrm{S}$, Mameli $\mathrm{F}$, et al. Cerebellar transcranial direct current stimulation impairs the practice-dependent proficiency increase in working memory. J Cogn Neurosci. 2008;20(9):1687-97.

17. Pope PA, Miall RC. Task-specific facilitation of cognition by cathodal transcranial direct current stimulation of the cerebellum. Brain Stim. 2012;5(2):84-94.

18. Macher K, Bohringer A, Villringer A, Pleger B. Cerebellar-parietal connections underpin phonological storage. J Neurosci. 2014;34(14): 5029-37.

19. Grimaldi G, Manto M. Anodal transcranial direct current stimulation (tDCS) decreases the amplitudes of long-latency stretch reflexes in cerebellar ataxia. Ann Biomed Eng. 2013;41(11):2437-47.

20. Grimaldi G, Oulad Ben Taib N, Manto M, Bodranghien F. Marked reduction of cerebellar deficits in upper limbs following transcranial cerebello-cerebral DC stimulation: tremor reduction and reprogramming of the timing of antagonist commands. Front Syst Neurosci. 2014;8:9.

21. Brookhart JM, Blaachly PH. 171. Cerebellar unit responses to D.C. polarization. Am J Physiol. 1952;171:711

22. Dundas JE, Thickbroom GW, Mastaglia FL. Perception of comfort during transcranial DC stimulation: effect of $\mathrm{NaCl}$ solution concentration applied to sponge electrodes. Clin Neurophysiol. 2007;118(5): 1166-70.

23. Sadnicka A, Kassavetis P, Saifee TA, Parees I, Rothwell JC, Edwards MJ. Cerebellar transcranial direct current stimulation does not alter motor surround inhibition. Int J Neurosci. 2013;123:425-32.

24. Parazzini M, Rossi E, Ferrucci R, Liorni I, Priori A, Ravazzani P. Modelling the electric field and the current density generated by cerebellar transcranial DC stimulation in humans. Clin Neurophysiol. 2014;125(3):577-84.

25. Mehrabyan A, Guest S, Essick G, McGlone F. Tactile and thermal detection thresholds of the scalp skin. Somatosens Mot Res. 2011;28(3-4):31-47.

26. Brunoni AR, Nitsche MA, Bolognini N, Bikson M, Wagner T, Merabet L, et al. Clinical research with transcranial direct current stimulation (tDCS): challenges and future directions. Brain Stim. 2012;5(3):175-95. 